\title{
Morphology and Anatomy of the Cordia trichotoma (Vell.) Arrab. ex I. M. Johnst diaspore (Boraginaceae)
}

\author{
Luiz Antonio de Souza* \\ Departamento de Biologia; Universidade Estadual de Maringá; Av. Colombo, 5790; lasouza@uem.br; 87020-900; \\ Maringá - PR - Brasil
}

\begin{abstract}
This study analyzed the morphology and anatomy of the Cordia trichotoma (Vell.) Arrab. ex I. M. Johnst diaspore. The objectives were: the structural analysis of the calyx and corolla that persisted in the ripe fruit and acted in the anemocoric dispersion process; the vascularization of the gynoecium for better understanding of the carpel/locule number of the ovary; nectary structure; and the anatomical analysis of the developmental pericarp and seed for better definition of the fruit type. The results showed that the perianth had aerenchyma and the ovary was 2- 4locule forming endothelium and false septum. The fruit was drupoid nuculanium and the seed was exotestal.
\end{abstract}

Key words: Anatomy, perianth, nectary, fruit, seed

\section{INTRODUCTION}

The Cordia trichotoma (Vell.) Arrab. ex I. M. Johnst (louro or louro-pardo) is a tree 20-30 meters tall, deciduous pioneer, heliophyte, selective xerophyte that occurs in more open and secondary semi-deciduous pluvial forest. Its wood is used for making the luxury furniture, for the ornamental covering etc. (Lorenzi, 1992). In Brazil, this species occurs from the Amazonas State to Rio Grande do Sul State. It is also present in the south of Bolivia, in Paraguai and north of Argentina (Smith, 1970).

The diaspore of this species is constituted by the fruit totally contained by the corolla tube and calyx, topped by the enlarged persistent base of the style (Smith, 1970). The fruit is drupaceous (Taroda and Gibbs, 1986). Barroso et al. (1999), however, classified it as drupoid with anemocoric dispersion. The ovary is considered as 2-carpellate with the 4-locules and 4-ovules, only one developing in the seed (Taroda and Gibbs, 1986). However, the structural observations of the flower showed that the locule number could vary along the ovary, from two to four, staying with four locules in the mature fruit.

In spite of the economical and ecological importance and difficulties of understanding of the ontogenetic process of the fruit of C. trichotoma, the literature doesn't show structural studies about the diaspore in the development of this species. Thus, the aim of this work was to: 1) the structural analysis of the calyx and corolla that persisted in the ripe fruit and acted in the anemocoric dispersion process; 2) the vascularization of the gynoecium for better understanding of the

\footnotetext{
* Author for correspondence
} 
carpel/locule number of the ovary; and 3) the anatomical analysis of the developmental pericarp and seed for better definition of the fruit type.

\section{MATERIALS AND METHODS}

The pre-anthesis and post-anthesis flowers and fruits in different development phases were collected from two $C$. trichotoma specimens. The studied material was deposited in the Herbarium of the State University of Maringá (HUM): Cordia trichotoma (Vell.) Arrab. ex I. M. Johnst. Estado do Paraná. Maringá, Brasil, Janunzzi 10143, 09-42003.

Semi-permanent slides with the cross- and longitudinal sections of the material (done freehand) using safranin and astra blue were made. The sections of the material fixed in FAA 50 and embedded in the paraffin wax were also obtained using the microtome techniques (Johansen, 1940) and were stained using Ehrlich hematoxylin and safranin (Johansen, 1940), in accordance with the simplified method of Dnyansagar (1958). The microchemical tests were carried out for the lipids (Sudan IV), starch (IKI) and lignin (phloroglucinol and sulfuric acid) (Johansen, 1940; Berlyn and Miksche, 1976).

The morphological description of the developing fruits and seeds was based on Corner (1976), Roth (1977) and Barroso et al. (1999). The drawings were made using an optical microscope and a stereomicroscope, equipped with a lucid camera.
The respective micrometric scales were prepared in the same optical conditions as the drawings.

\section{RESULTS AND DISCUSSION}

\section{Flower morphology}

The C. trichotoma flower (Fig. 1A) was dichlamydeous, heterochlamydeous, actinomorphic and hypogynous. The green synsepalous calyx and white sympetalous corolla stayed during the whole development of the fruit until its mature phase, when they acquired the brown color. The fruit with the perianth (Fig. $1 \mathrm{~B}$ ) constituted the diaspore that presented the anemocoric dispersion.

\section{Calyx and corolla anatomy}

The calyx had a uniseriate abaxial face epidermis, with cuticle, periclinal thick-walled cells (Fig. 3 A), multicellular stalked star-shaped tector trichomes (Fig. 2 A, B), glandular trichomes with bicellular pedicel and unicellular apex, and stomatal complexes (Fig. 2 C). The adaxial face epidermis (Fig. 3 A) was also uniseriate and possessed cuticle, tabular elongate cells, unicellular tector trichomes of round extremity (Fig. 2 D) and multicellular pointed tector trichomes of small size (Figs. 2 F, 3 A). In the mesophyll, there was little collenchyma under the abaxial face epidermis, parenchyma with cells more or less isodiametric, discontinuous middle strip of fibres, and spongy parenchyma with elongated cells (Figs. 2 F, 3 A).

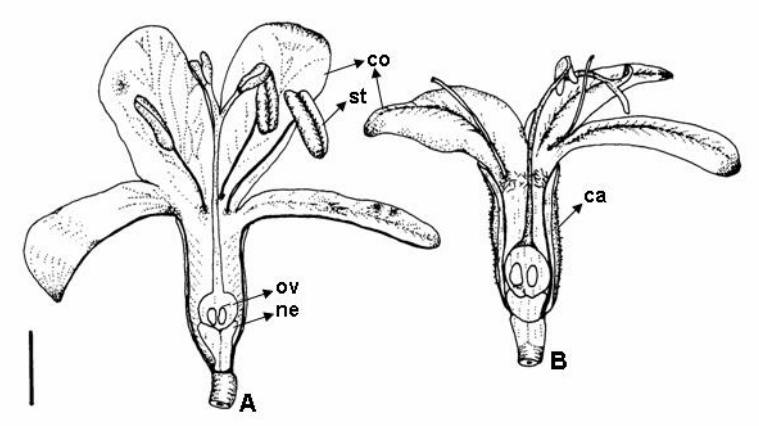

Figure 1 - Cordia trichotoma flower (A) and mature fruit (B) in longitudinal section. Abbreviations: ca: calyx; co: corolla; ne: nectary; ov: ovary; st: stamen. (Bar: 4mm). 


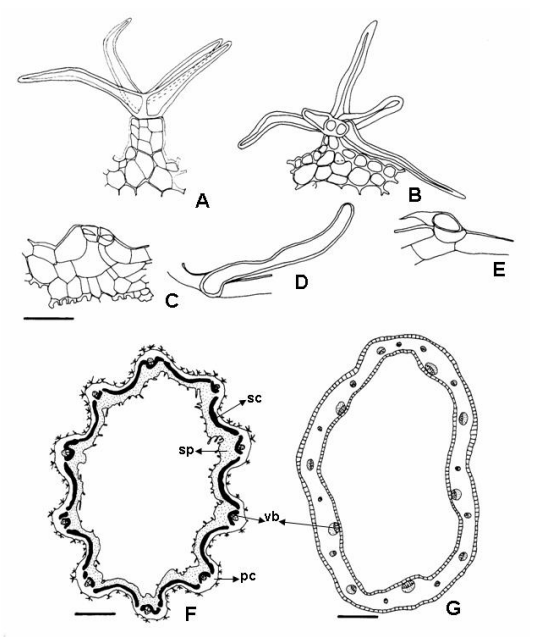

Figure 2 - Perianth structure of Cordia trichotoma. A, B: trichomes of calyx abaxial face epidermis; C: stomata of the calyx abaxial face epidermis; D, E: trichomes of calyx adaxial face epidermis; F: diagram of calyx in cross-section; G: diagram of corolla in cross-section. Abbreviations: pc: parenchyma and collenchyma; sc: sclerenchyma; sp:

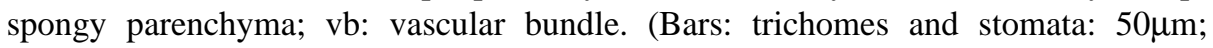
diagrams: $1 \mathrm{~mm})$.

The collateral vascular bundles occurred next to the fibres strip (Figs. 2 F, 3 A). The corolla (Fig. 3 B) presented glabrous epidermis of similar structure in both the faces, with the cuticle and cuboid or elongate cells in the cross-section.

The mesophyll was homogeneous and was constituted of spongy parenchyma (Fig. 3 B). The vascular bundles were collateral and were disposed in the middle area of the mesophyll (Figs. 2 G, 3 B).

The calyx seemed to have a double function in the process of anemocoric dispersion of $C$. trichotoma. The abaxial face epidermis with thick-walled cells and the mesophyll schlerenchyma of the sepals had a protecting function and the mesophyll aerenchyma located under the epidermic adaxial face was auxiliary in the wind dispersion of the diaspore The petals with larger superficial area and aerenchymatous mesophyll acted only in the anemocoric dispersion of the diaspore.

The C. trichotoma sepals seemed to differ in the general structure of the calyx presented by Esau (1959), Fahn (1990) and Souza et al. (2001), although Mauseth (1988) suggested that the sepals were extremely flexible evolutionarily. The petals of this species seemed better adapted to the structural description of Esau (1959), Mauseth (1988), Fahn (1990) and Souza et al. (2001, 2004).

\section{Pericarp structure in development Gynoecium structure}

The gynoecium vascularization of the $C$. trichotoma was made by a vascular tissue cylinder, organized around the parenchymatous pith in the flower pedicel (Fig. 4 A). In the receptacle, the vascular tissues formed the two traces of semilunar outline, one for each carpel (Fig. 4 B, C). In the base (Fig. 4 D) and along the ovary (Fig. 4 E, F, G, H), each trace was organized in the vascular bundles of each carpel, which included one dorsal vascular bundle, several lateral vascular bundles and three marginal or ventral vascular bundles. In this style, only two vascular bundles and the central transmitting tissue (Fig. 4 I) occurred. 


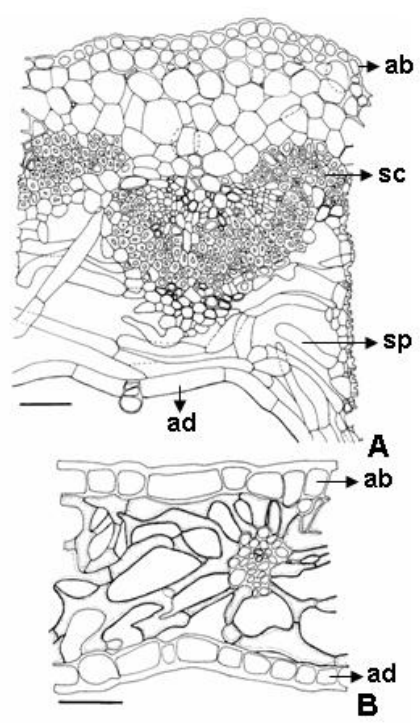

Figure 3 - Details of perianth structure of Cordia trichotoma in cross-sections. A: calyx; B: corolla. Abbreviations: ab: abaxial epidermis; ad: adaxial epidermis; sc: sclerenchyma; sp: spongy parenchyma. (Bars: $50 \mu \mathrm{m})$.

In the base of the ovary, there was just one locule with the developed placenta that moved forward to the central region of the ovary (Fig. 4 D, E, F, G), constituting a false septum in the ovarian apical portion (Figs. $4 \mathrm{H}, 5 \mathrm{~A}$ ). In consequence, the ovary presented 4-locules (Figs. $4 \mathrm{H}, 5 \mathrm{~A}$ ). From the floral pedicel and for the whole gynoecium, high number of secretory cells was observed (Fig. 4 A, B, C, D, E, F, G, H, I). The Cordia ovary was described as 4-locules (Taroda and Gibbs, 1986). However, the ovary cross-sections of $C$. trichotoma showed that it was only 2-locules in the base and 4-locules in the apical region, which was due to the formation of a false septum of placentary origin. The C. trichotoma ovary (Fig. 5 A, C) had uniseriate and glabrous outer or dorsal epidermis. The epidermis was covered with a cuticle and it didn't possess stomata.

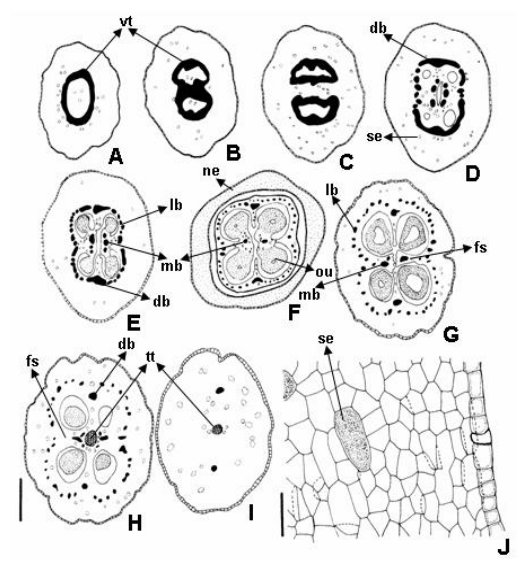

Figure 4 - Diagrams of gynoecium vascularization and nectary structure of Cordia trichotoma. A: floral pedicel in cross-section; B, C: floral receptacle in cross-sections; D, E, F, G, H: ovary in cross-sections; I: style in cross-section; J: detail of nectary in longitudinal section. Abbreviations: db-dorsal vascular bundle; fs: false septum; lb: lateral vascular bundle; mb: marginal vascular bundle; ne: nectary; ou: ovule; se: secretory cells; tt: transmitting tissue; vt: vascular tissue. (Bars: diagrams: 0.5mm; detail: $30 \mu \mathrm{m}$ ). 
The epidermic cells were cuboid with thickened outer periclinal cell-walls. The inner or ventral epidermis was covered with thin cuticle, was glabrous and had tabular cells. The ovary mesophyll was parenchymatous with the angular, isodiametric and little elongate cells. The nectary occurred in the base of the ovary and fruit involving them partially (Fig. $1 \mathrm{~A}, \mathrm{~B}$ ). It was formed by a uniseriate epidermis and nectariferous tissue with the secretory cells (Fig. $4 \mathrm{~J}$ ).

\section{Pericarp structure}

The outer or dorsal ovary epidermis of $C$. trichotoma suffered little alteration in the differentiation of the exocarp. In the differentiated exocarp (Fig. 5 B, D), the cell-walls were thick, besides the anticlinal cell-walls, and the cuticle came rugose. The inner or ventral epidermis suffered deep modification to form the endocarp, having their cells strongly sclerefied and lignified (Fig. 5 D). The differentiation of the ovary mesophyll in mesocarp also showed significant alterations. In the mature mesocarp, these were narrow collenchymatous cell-layer under the exocarp, multiseriate parenchyma, and one or two strata of lignified and abundantly pitted brachysclereid and macrosclereid close to the endocarp (Fig. 5 D). The vascularization of the mature pericarp (Fig. 5 B) was similar the one of the ovary.

The Cordia fruit is considered as a drupe (Smith, 1970; Taroda and Gibbs, 1986). However, being taken into account the terminology of Barroso et al. (1999), the fruit of C. trichotoma can be classified as a drupoid type nuculanium. For Souza (2006) and Barroso et al. (1999) the fruit drupoid with only one pyrene (endocarp), with central space not divided, drupe is denominated. In another way, if the pyrene is loculate or if there are two or more free pyrenes (Fig. $5 \mathrm{~B}$ ), the drupoid is called nuculanium.

Roth (1977) did not make a distinction between the drupe and nuculanium. According to him, the "classical" type of drupe developed from a single carpel or, at least, from a carpel favored in its growth, producing the single seed, whereas the remaining carpels of the ovary became reduced. Maybe, for that reason, some authors classified the C. trichotoma fruit as a drupe, being taken into account that the mature fruit (Fig. 7 A) had a fertile carpel, a seed and an aborted carpel.

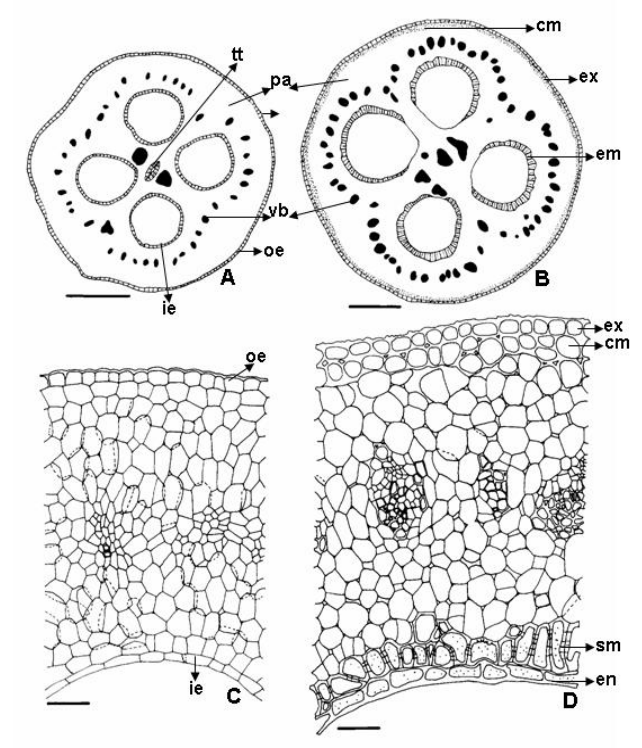

Figure 5 - Ovary and fruit structure of Cordia trichotoma in cross-sections. A, C: diagram and detail of the ovary; B, D: diagram and detail of the fruit. Abbreviations: cm: collenchymatic mesocarp; em: endocarp and inner mesocarp; en: endocarp; ex: exocarp; ie: inner epidermis; oe: outer epidermis; pa: parenchyma; sm: sclerenchymatic mesocarp; tt: transmitting tissue; vb: vascular bundle. (Bars: diagrams:0.5mm; details: $50 \mu \mathrm{m})$. 


\section{Seed structure in development}

The seed of $C$. trichotoma originated from the suspended, unitegmic, tenuinucellate ovule (Fig. 6 A). In the analysis of the ovule, the size of the antipodes (Fig. $6 \mathrm{~A}, \mathrm{C}$ ) persisted for some time in the seed in development (Fig. 6 E). The only ovule integument of $C$. trichotoma was multiseriate (Fig. $6 \mathrm{~B}, \mathrm{D})$ and presented endothelium (Fig. 6 A, C) that was formed by the basal epidermic cells of the inner integument that had dense cytoplasm.

The presence of endothelium in the ovule integument of $C$. trichotoma was not referred to by Corner (1976), although the author registered it for another genus of the family Boraginaceae. The endothelium occurs mainly in families that show unitegmic, tenuinucellate ovules (Kapil and Tiwari, 1978; Dahlgren, 1991). Souza (1988), analyzing the seed of Lonchocarpus muehlbergianus Hassl., and Maheshwari (1971) suggested that the endothelium was a nutritive layer whose main function was to serve as the intermediary for the transport of the food materials from the integument to the embryo sac.

In the young seed of $C$. trichotoma, a short funicle was noticed, from which the vascular bundle penetrated that exhibited the prechalazal and postchalazal branches (Fig. $6 \mathrm{~F}$ ). The immature coat-seed still presented the endothelium well developed and the outer epidermis possessed thinwalled columnar cells (Fig. 6 E).The mature seed possessed straight embryo with plicate cotyledons (Fig. 7 A) and oily endosperm (Fig. 7 D). The cotyledons had asymmetrical heterogeneous mesophyll (Fig. 7 E). The seed was exotestal with outer epidermis (Fig. 7 B) of the coat-seed with reticulate thickened cell-walls (Fig. $7 \mathrm{C}$ ). One or two cell layers of the coat-seed mesophyll presented similar cell-walls to the one of the outer epidermis (Fig. 7 B).

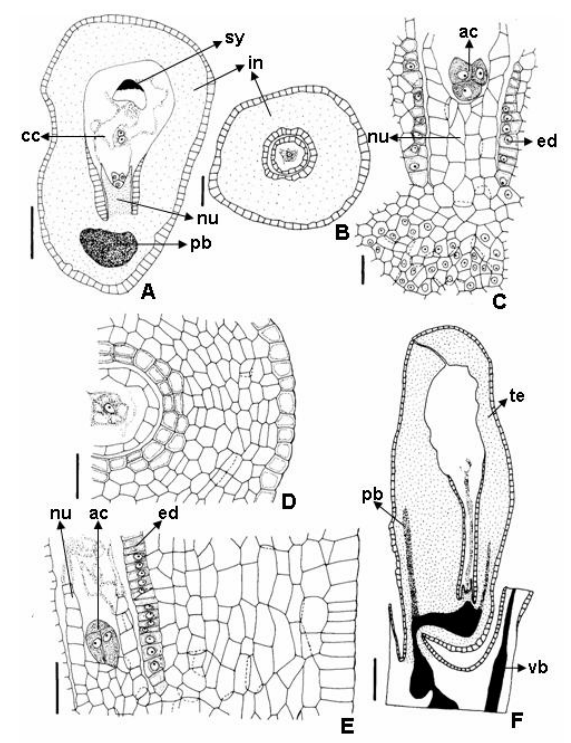

Figure 6 - Ovule and young seed structure of Cordia trichotoma. A, B: ovule diagrams in crossand longitudinal section; C, D: ovule details of the figures A and B; E, F: detail and diagram of the young seed in longitudinal section. Abbreviations: ac: antipodal cells; cc: central cell; ed: endothelium; in: integument; nu: nucellus; pb: procambial bundle; sy: synergid; te: testa; vb: vascular bundle. (Bars: $100 \mu \mathrm{m}, 50 \mu \mathrm{m}, 20 \mu \mathrm{m}, 30 \mu \mathrm{m}, 40 \mu \mathrm{m}$, $200 \mu \mathrm{m}$, respectively). 


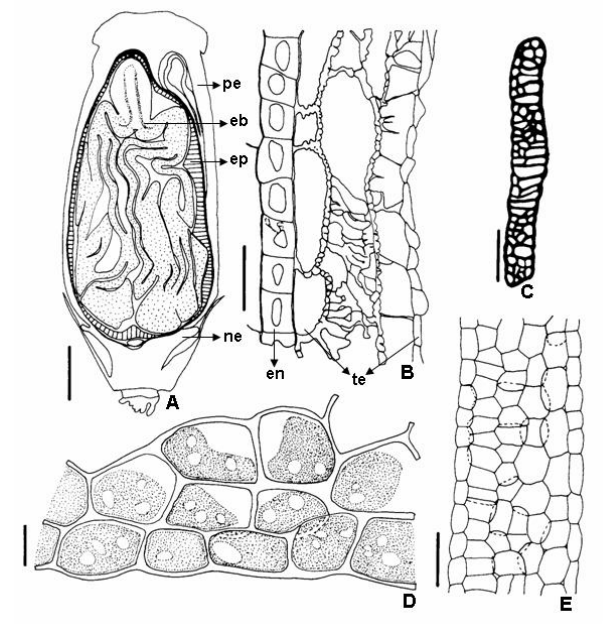

Figure 7 - Mature fruit and seed structure of Cordia trichotoma in longitudinal sections. A: fruit diagram; B: endocarp and testa in detail; C: testa cell with reticulate thickened cell-walls; D: detail of the endosperm; E: detail of cotyledon. Abbreviations: eb: embryo; en: endocarp; ep: endosperm; ne: nectary; pe: pericarp; te: testa. (Bars: $1 \mathrm{~mm}, 30 \mu \mathrm{m}, 20 \mu \mathrm{m}$, $15 \mu \mathrm{m}, 50 \mu \mathrm{m}$, respectively).

Several ovule and mature seed characters presented by Corner (1976) for Boraginaceae genera were observed in C. trichotoma. However, some characters were different in this species which included the presence of ovule endothelium, persistence of antipodal cells in the initial developmental phases of the seed, vascular supply of the coat-seed with prechalazal and postchalazal branches and reticulate thickened cell-walls in the coat-seed mesophyll.

\section{RESUMO}

Esse estudo analisa a morfologia e anatomia do diásporo de Cordia trichotoma (Vell.) Arrab. ex I. M. Johnst. Os objetivos do estudo são: a análise estrutural do cálice e corola que persistem no fruto maduro e atuam no processo de dispersão anemocórica; a vascularização do gineceu para melhor entendimento do número de carpelos/lóculos do ovário; a estrutura do nectário; e a análise anatômica do pericarpo e semente em desenvolvimento, para melhor definição do tipo de fruto. $\mathrm{O}$ perianto tem aerênquima. $\mathrm{O}$ ovário tem 2 e 4 lóculos e forma endotélio e septo falso. $\mathrm{O}$ fruto é drupóide nuculânio e a semente é exotestal.

\section{REFERENCES}

Barroso, G. M.; Morim, M. P.; Peixoto, A. L. and Ichaso, C. L. F. (1999), Frutos e sementes Morfologia aplicada à sistemática de dicotiledôneas. Ed. UFV, Viçosa.

Berlyn, G. P. and Miksche, J. P. (1976), Botanical microtechnique and cytochemistry. The Iowa State University Press, Ames.

Corner, E. J. H. (1976), The seeds of dicotyledons. Vol. I. Cambridge University Press, Cambridge.

Dahlgren, G. (1991), Steps toward a natural system of the dicotyledons: embryological characters. Aliso, 13, 107-165.

Dnyansagar, V.R. (1958), Embryological studies in the Leguminosae VIII. Acacia auriculaeformis A Cunn., Adenanthera pavonina Linn., Calliandra grandiflora Benth. Lloydia, 21, 1-25.

Esau, K. (1959), Anatomía vegetal. Ediciones Omega, Barcelona.

Fahn, A. (1990), Plant anatomy. Pergamon Press, Oxford.

Johansen, D. A. (1940), Plant microtechnique. McGraw-Hill, New York.

Kapil, R. N. and Tiwari, Y. S. C. (1978), The integumentary tapetum. Bot. Rev., 44, 457-490.

Lorenzi, H. (1992), Árvores brasileiras - manual de identificação e cultivo de plantas arbóreas nativas do Brasil. Editora Plantarum, Nova Odessa.

Maheshwari, P. (1971), An introduction to the embryology of angiosperms. Tata McGraw-Hill Publishing Company, New Delhi. 
Mauseth, J. D. (1988), Plant anatomy. The Benjamin/Cummings Publishing Company, Menlo Park.

Roth, I. (1977), Fruits of angiosperms. In-Encyclopedia of Plant Anatomy, ed. K. Linsbauer, F. G. Tischler and A. Pascher. Gebrüder Borntraeger, Berlin, pp. 368-431.

Smith, L. B. (1970), Boragináceas. In-Flora Ilustrada Catarinense, ed. P. R. Reitz. Herbário Barbosa Rodrigues, Itajaí, pp. 1-85.

Souza, L. A. (1988), Anatomia de estádios de desenvolvimento da semente de Lonchocarpus muehlbergianus Hassl. (Leguminosae - Faboideae). Garc. Orta, Sér. Bot., 10, 1-9.

Souza, L. A. (2006), Fruto. In-Anatomia do fruto e da semente, ed. L. A. Souza. Editora Universidade Estadual de Ponta Grossa, Ponta Grossa, pp. 10-123
Souza, L. A.; Moscheta, I. S.; Mourão, K. S. M. and Silvério, A. (2001), Morphology and anatomy of the flowers of Trichilia catigua A. Juss., T. elegans A. Juss. and T. pallida Sw. (Meliaceae). Braz. Arch. Biol. Technol., 44, 383-394.

Souza, L. A.; Moscheta, I. S.; Mourão, K. S. M. and Rosa, S. M. (2004), Morphology and anatomy of the flower and anthesis of Metrodorea nigra St. Hill. (Rutaceae). Braz. Arch. Biol. Technol., 47, 107-112.

Taroda, N. and Gibbs, P. (1986), Studies on the genus Cordia L. (Boraginaceae) in Brazil. 1. A new infrageneric classification and conspectus. Rev. Bras. Bot., 9, 1-6.

Received: May 12, 2006; Revised: February 07, 2007; Accepted: December 27, 2007. 